\section{JURNAL EKONOMI EFEKTIF}

ISSN : $2622-8882$, E-ISSN : 2622-9935

Jurnal Ekonomi Efektif, Vol. 4, No. 2, Januari 2022

@Prodi Manajemen Fakultas Ekonomi

Universitas Pamulang

\title{
PENGARUH NON PERFORMING LOAN TERHADAP RETURN ON ASSET PADA PT PERMATA BANK, TBK PERIODE 2010-2020
}

\author{
Ismail $^{1}$, Hendro Waryanto ${ }^{2 *}$ \\ Universitas Pamulang, Tangerang Selatan, Banten, Indonesia \\ ismail.altegali@gmail.com ${ }^{1}, \underline{\text { dosen00254@unpam.ac.id }{ }^{2 *}}$
}

Manuskrip: November -2021; Ditinjau: November: -2021; Diterima: Desember-2021; Online: Januari -2022; Diterbitkan: Januari-2022

\begin{abstract}
ABSTRAK
Penelitian ini bertujuan untuk mengetahui pengaruh Non Performing Loan terhadap Return on Asset pada PT. Permata Bank, Tbk. Metode yang digunakan adalah explanatory research. Teknik analisis menggunakan analisis statistik dengan pengujian regresi, korelasi, determinasi dan uji hipotesis. Hasil penelitian ini variabel Non Performing Loan diperoleh nilai rata-rata sebesar 3,31\%. Variabel Non Performing Loan diperoleh nilai rata-rata 2,68\%. Non Performing Loan tidak berpengaruh positif dan signifikan terhadap Return on Asset dengan nilai persamaan regresi $Y=4,039-0,409 X$, dan nilai koefisien korelasi -0,441 atau memiliki tingkat hubungan yang negatif sedang dengan nilai determinasi $19,8 \%$. Uji hipotesis diperoleh signifikansi $0,174>0,05$.
\end{abstract}

Kata Kunci: Non Performing Loan, Non Performing Loan

\section{ABSTRACT}

This study aims to determine the effect of Non Performing Loan on Return on Assets at PT. Permata Bank, Tbk. The method used is explanatory research. The analysis technique uses statistical analysis with regression, correlation, determination and hypothesis testing. The results of the study on the Non Performing Loan variable obtained an average value of $3.31 \%$. Non-Performing Loan variable obtained an average value of 2.68\%. Non-Performing Loans have no positive and significant effect on Return on Assets with the regression equation $Y=$ 4.039 - 0.409X, and the correlation coefficient -0.441 or has a moderate negative relationship with a determination value of $19.8 \%$. Hypothesis testing obtained a significance of 0.174> 0.05 .

Keywords: Non Performing Loan, Non Performing Loan 


\section{PENDAHULUAN}

\section{A. Latar Belakang}

Industri perbankan merupakan industri yang syarat terutama karena melibatkan pengolahan uang masyarakat dan diputar dalam bentuk berbagai investasi, seperti pemberian kredit, pembelian surat-surat berharga dan penambahan dana lainnya. kondisi perbankkan di indonesia selama tahun 2013 - 2017 merupakan periode yang penuh dengan dinamika bagi industri perbankkan nasional.ditengah beratnya tantangan yang di hadapi,bank pada umumnya mampu mempertahankan kinerja yang positif. Profitabilitas, likuiditas, dan solvabilitas bank stabil pada tingkat yang memadahi. namun demikian,fungsi intermediasi maih terkendaala akibat perubahan kondisi perekonomian yang kurang menguntungkan.

Bank merupakan lembaga intermediasi bagi pihak yang berkelebihan dana dengan pihak yang berkekurangan dana. Dimana bank memiliki beberapa fungsi, salah satunnya adalah Agent Of Trust. Agen Of Trust yang berarti dalam kegiatan usahannya bank mengandalkan kepercayaan (trust)masyarakat. Masyarakat percaya bahwa uangnya tidak disalahgunakan oleh bank. uangnya akan dikelola dengan baik dan bank tidak akan bangrut.

Untuk mengukur kinerja perusahaan yang baik adalah profit, maka dapat digunakkan analisis profitabilitas. Profitability Analysis yang implementasinya adalah Profitability Ratio disebut juga operating ratio, ada dua tipe rasio yakni Margin On Sale untuk mengukur kemampuan perusahaan dalam mengendalikan pengeluaran yang hubungannya dengan penjualan, melalui Gross Profit Margin, Operating Margin dan Net Profit Margin.

Bank indonesia juga lebih mengutamakan nilai profitabilitas suatu bank yang diukur dengan ROA dibandingkan dengan ROA karena bank indonesia lebih mengutamakan nilai profitabilitas suatu bank yang di ukur dengan asset yang danannya sebagian besar berasal dari simpanan masyarakkat sehingga ROA lebih mewakili dalam mengukur tingkat profitabilitas bank.

PT. PermataBank, Tbk. merupakan perusahaan yang bergerak dalam bidang perbankan, yaitu kegiatannya menghimpun dana dari masyarakat (berupa tabungan, deposito, giro dan investasi) dan menyalurkan kepada masyarakat berupa pembelian kredit. Oleh karenannya, Permata Bank menyadari akan pentingnya menjaga dan meningkatkan kesehatan kinerjanya dalam upaya mempertahankan eksistensi bisnis melalui peningkatan profitabilitas. Dalam upaya meningkatkan Return Of Assets (ROA), manajemen bank juga perlu untuk memperhatikan besarnya likuiditas. Tingkat kemampuan bank memenuhi kewajiban keuangan yang harus dibayar (likuiditas). Tingkat likuiditas dapat diukur antara lain dengan rasio keuangan yaitu Loan To Desposit Ratio (LDR) yang merupakan rasio untuk menilai likuiditas suatu bank dengan cara membagi jumlah kredit yang diberikan oleh bank terhadap dana oleh pihak ketiga.

Berikut ini data pencapaian Loan depsoit Ratio dan Return On Asset PT. Permata Bank Tahun 2010-2020, sebagai berikut:

Tabel 1. Nilai NPL dan ROA PT. Permata Bank Tahun 2010-2020

\begin{tabular}{c|c|c|} 
Tahun & NPL & ROA \\
\hline 2010 & 0.0462 & $1.72 \%$ \\
\hline 2011 & $3.54 \%$ & $3.98 \%$ \\
\hline 2012 & $2.14 \%$ & $1.92 \%$ \\
\hline 2013 & $2.66 \%$ & $1.74 \%$ \\
\hline 2014 & $3.78 \%$ & $2.72 \%$ \\
\hline 2015 & $2.35 \%$ & $1.65 \%$ \\
\hline
\end{tabular}




\begin{tabular}{c|c|c|}
\hline 2016 & $2.13 \%$ & $5.23 \%$ \\
\hline 2017 & $2.11 \%$ & $3.27 \%$ \\
\hline 2018 & $2.17 \%$ & $3.93 \%$ \\
\hline 2019 & $5.13 \%$ & $1.21 \%$ \\
\hline 2020 & $5.86 \%$ & $2.15 \%$ \\
\hline Rata-rata & $3,32 \%$ & $2,68 \%$ \\
\hline
\end{tabular}

Berdasarkan data pada tabel di atas, menunjukkan bahwa pencapaian Loan Deposit Ratio (LDR) PT. Permata Bank Tbk Tahun 2010-2020 berluktuasi. pncapaian terendah dicapai pada tahun 2017 yang hanya mencapai sebesar 2,11\% dan pencapaian tertinggi terjadi tahun 2019 yang mampu mencapai 5,86\%. Secara rata-rata dicapai 3,32\% per tahunnya.

Sedangkan profitabilitas yang diukur dengan Return on Asset (ROA) menunjukkan bahwa pencapaian tahun 2010-2020 juga berluktuasi. pncapaian terendah dicapai pada tahun 2019 yang hanya mencapai sebesar 1,121 dan pencapaian tertinggi terjadi tahun 2016 yang mampu mencapai 5,238\%. Secara rata-rata dicapai 2,68\% per tahunnya.

Masalah pemberian kredit Loan To Deposit Ratio (LDR) yang sering dihadapi bisnis perbankkan adalah adanya persaingan tajam yang tidak seimbang yang dapat menimbulkan ketidak efisien manajemen yang berakibat pada pendapatan dan munculnya kredit bermasalah yang dapat menurunkan laba. Kredit bermasalah akan mempengaruhi permodalan yang juga dapat menyebabkan bank mengalami masalah likuiditas.

Kredit yang diberikan oleh bank merupakan bagian terbesar dari aset yang dimiliki oleh bank yang bersangkutan oleh karna itu, kegiatan perkreditan merupakan tulang punggung dari kegiatan utama bank melihat peranan kredit yang sangat besar dalam perekonomian tentunya pemerintah dan perbankan harus menerapkan kebijakan yang dapat dalam mengatur keseimbangan kredit nasional. Kredit menjadi sumber pendapatan dan keuntungan bank yang terbesar. Disamping itu kredit juga merupakan jenis kegiatan penanaman dana yang sering menjadi penyebab utama suatu bank dalam menghadapi masalah besar maka tidak berlebihan apabila dikatakan bahwa usaha bank sangat dipengaruhi oleh keberhasilan mereka mengelola kredit usaha bank yang berhasil mengelola kreitnya akan berkembang, sedangkan usaha bank yang selalu di rong-rong kredit bermasalah akan mundur.

Pada dasarnya semua bisnis tidak terlepas dari resiko kegagalan demikian pula dengan dunia perbankan pemberian kredit yang dilakukan oleh bank mengandung resiko yaitu berupa tidak lancarnya pembayaran kredit atau dengan kata lain krdit bermasalah Non Performing Loan (NPL) sehingga akan mempengaruhi kinerja bank data terbaru bank indonesia (BI) mengungkapkan bahwa kualitas kredit perbankkan cenderung mengalami penurunan. Adapun indikasinya terlihat sangat jelas dari peningkatan kredit macet atau Non Performing loan (NPL). Untuk Non Performing Loan (NPL) bank indonesia telah menentukan sebesar 5\%. Apabila bank mampu menekan Rasio Non Performing Loan (NPL) dibawah 5\%, maka potensi keuntungan yang akan diperoleh akan semakin besar, karena bank-bank akan menghemat uang yang diperlukan untuk membentuk cadangan kerugian kredit bermasalah penyisihan penghapusan aktiva produktif (PPAP). melambatntya pertumbuhan ekonomi berdampak pada pertumbuhan kredit dan dana pihak ketiga, serta kenaikan biaya cadangan kredit bermasalah maupun beban oprasional

Berdasarkan uraian di atas, maka penulis tertarik melakukan penelitian dengan judul "Pengaruh Non Performing Loan (NPL) Terhadap Return on Asset (ROA) Pada 
PT. Permata Bank, Tbk Periode 2010-2020”.

\section{B. Rumusan Masalah}

1. Bagaimana Non Performing Loan pada PT. Permata Bank, Tbk ?.

2. Bagaimana Return on Asset pada PT. Permata Bank, Tbk ?.

3. Adakah pengaruh antara Non Performing Loan terhadap Return on Asset pada PT. Permata Bank, Tbk?.

\section{Tujuan Penelitian}

a. Untuk mengetahui kondisi Non Performing Loan pada PT. Permata Bank, Tbk.

b. Untuk mengetahui kondisi Return on Asset pada PT. Permata Bank, Tbk.

c. Untuk mengetahui pengaruh antara Non Performing Loan terhadap Return on Asset pada PT. Permata Bank, Tbk.

\section{METODE PENELITIAN}

\section{Populasi}

Populasi dalam penelitian ini laporan keuangan PT. Permata Bank, Tbk selama 11 tahun

\section{Sampel}

Teknik pengambilan sampling dalam penelitian ini adalah samplel jenuh, dimana semua anggota populasi dijadikan sebagai sampel. Dengan demikian sampel dalam penelitian ini laporan keuangan PT. Permata Bank, Tbk selama 11 tahun.

\section{Jenis Penelitian}

Jenis penelitian yang dipakai adalah asosiatif, dimana tujuannya adalah untuk mengetahui mencari keterhubungan antara variabel independen terhadap variabel dependennya

\section{Metode Analisis Data}

Dalam menganalisis data digunakan uji validitas, uji reliabilitas, analisis regresi linier sederhana, koefisien korelasi, koefisien determinasi dan uji hipotesis.

\section{HASIL PENELITIAN}

\section{Analisis Deskriptif}

Pada pengujian ini digunakan untuk mengetahui skor minimum dan maksimum skor tertinggi, ratting score dan standar deviasi dari masing-masing variabel. Adapun hasilnya sebagai berikut:

Tabel 1. Hasil Analisis Descriptive Statistics

\section{Descriptive Statistics}

\begin{tabular}{lr|r|r|r|r} 
& $\mathrm{N}$ & \multicolumn{1}{c}{ Minimum } & Maximum & \multicolumn{1}{c|}{ Mean } & $\begin{array}{c}\text { Std. } \\
\text { Deviation }\end{array}$ \\
\hline Non Performing Loan & 11 & 2.11 & 5.86 & 3.3173 & 1.36562 \\
\hline Return On Asset & 11 & 1.21 & 5.23 & 2.6836 & 1.26452 \\
\hline Valid N (listwise) & 11 & & & & \\
\hline
\end{tabular}

Pencapaian Non Performing Loan diperoleh nilai minimum sebesar $2,11 \%$ dan nilai maximum 5,86\% dengan rata-rata sebesar 3,31\% dengan standar deviasi $1,36 \%$. Sedangkan Pencapaian nilai Return on Asset diperoleh nilai minimum sebesar 1,21\% dan nilai maximum 5,23\% dengan rata-rata sebesar $2,68 \%$ dengan standar deviasi $1,26 \%$.

\section{Analisis Verifikatif}

Pada analisis ini dimaksudkan untuk mengetahui pengaruh variabel independen 
terhadap variabel dependen. Adapun hasil pengujian sebagai berikut:

\section{a. Analisis Regresi Linier Sederhana}

Uji regresi ini dimaksudkan untuk mengetahui perubahan variabel dependen jika variabel independen mengalami perubahan. Adapun hasil pengujiannya sebagai berikut:

Tabel 2. Hasil Pengujian Regresi Linier Sederhana

\begin{tabular}{|c|c|c|c|c|c|c|}
\hline \multirow{3}{*}{\multicolumn{2}{|c|}{ Model }} & \multicolumn{2}{|c|}{ Coefficients $^{\mathrm{a}}$} & \multirow{3}{*}{$\begin{array}{l}\text { Standardized } \\
\text { Coefficients } \\
\text { Beta }\end{array}$} & \multirow{3}{*}{$\mathrm{t}$} & \multirow{3}{*}{ Sig. } \\
\hline & & \multicolumn{2}{|c|}{$\begin{array}{l}\text { Unstandardized } \\
\text { Coefficients }\end{array}$} & & & \\
\hline & & B & Std. Error & & & \\
\hline 1 & (Constant) & 4.039 & .987 & & 4.092 & .003 \\
\hline & Non Performing Loan & -409 & 277 & -441 & -1.475 & 174 \\
\hline
\end{tabular}

a. Dependent Variable: Return On Asset

Berdasarkan hasil pengujian pada tabel di atas, diperoleh persamaan regresi $\mathrm{Y}$ $=4,039-0,409 X$. Dari persamaan tersebut dijelaskan sebagai berikut:

1) Konstanta sebesar 4,039 diartikan jika Non Performing Loan tidak ada, maka telah terdapat nilai Return on Asset sebesar 4,039 point.

2) Koefisien regresi Non Performing Loan sebesar -0,409, angka ini negatif artinya setiap ada peningkatan Non Performing Loan sebesar 0,409 point maka Return on Asset juga akan mengalami penurunan sebesar -0,409 point.

\section{b. Analisis Koefisien Korelasi}

Analisis koefisien korelasi dimaksudkan untuk mengetahui tingkt kesangat negatif sedangan hubungan dari variabel independen terhadap variabel dependen baik secara parsial maupun simultan. Adapun hasil pengujian sebagai berikut:

Tabel 3. Hasil Pengujian Koefisien Korelasi Non Performing Loan Terhadap Return on Asset. Correlations $^{\mathrm{b}}$

\begin{tabular}{llr|r} 
& & Non Performing Loan & \multicolumn{1}{c}{ Return On Asset } \\
\hline Non Performing Loan & Pearson Correlation & 1 & -.441 \\
\cline { 2 - 4 } & Sig. (2-tailed) & & .174 \\
\hline Return On Asset & Pearson Correlation & -.441 & 1 \\
\cline { 2 - 4 } & Sig. (2-tailed) & .174 & \\
\hline
\end{tabular}

*. Correlation is significant at the 0.05 level (2-tailed).

b. Listwise $\mathrm{N}=11$

Berdasarkan hasil pengujian diperoleh nilai korelasi sebesar -0,441 artinya Non Performing Loan memiliki hubungan yang negatif sedang terhadap Return on Asset.

\section{c. Analisis Koefisien Determinasi}

Analisis koefisien determinasi dimaksudkan untuk mengetahui besarnya persentase pengaruh dari variabel independen terhadap variabel dependen. Adapun hasil pengujian sebagai berikut:

Tabel 4. Hasil Pengujian Koefisien Determinasi Non Performing Loan Terhadap

\begin{tabular}{|c|c|c|c|c|}
\hline \multirow[b]{2}{*}{ Model } & \multicolumn{3}{|c|}{$\begin{array}{l}\text { Return on Asset. } \\
\text { Model Summary }\end{array}$} & \multirow[b]{2}{*}{$\begin{array}{l}\text { Std. Error of the } \\
\text { Estimate }\end{array}$} \\
\hline & $\mathrm{R}$ & R Square & Adjusted R Square & \\
\hline 1 & $.441^{\mathrm{a}}$ & .195 & .105 & 1.19613 \\
\hline
\end{tabular}


on Asset, sedangkan sisanya sebesar $81,2 \%$ dipengaruhi faktor lain.

\section{d. Uji Hipotesis}

Pengujian hipotesis dengan uji t digunakan untuk mengetahui hipotesis mana yang diterima. Rumusan hipotesis: Terdapat pengaruh yang signifikan antara Non Performing Loan terhadap Return on Asset.

Tabel 5. Hasil Uji Hipotesis Non Performing Loan Terhadap Return on Asset.

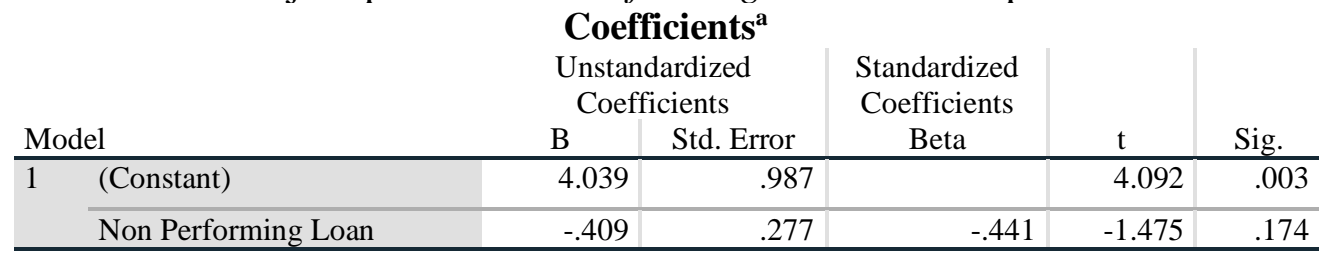

a. Dependent Variable: Return On Asset

Berdasarkan hasil pengujian pada tabel di atas, diperoleh nilai thitung $<\mathrm{t}$ tabel atau $(-1,479<2,262)$, dengan demikian hipotesis yang diajukan bahwa terdapat pengaruh yang signifikan atara Non Performing Loan terhadap Return on Asset ditolak.

\section{Pembahasan Hasil Penelitian}

\section{Kondisi Nilai Non Performing Loan}

Berdasarkan data empiris dan analisis data, variabel Non Performing Loan diperoleh nilai rata-rata per tahun sebesar 3,31\%.

\section{Kondisi Nilai Return on Asset}

Berdasarkan data empiris dan analisis data, variabel Return on Asset diperoleh nilai rata-rata per tahun sebesar $2,68 \%$.

\section{Pengaruh Non Performing Loan Terhadap Return on Asset}

Non Performing Loan berpengaruh signifikan terhadap Return on Asset dengan persamaan regresi $\mathrm{Y}=4,039$ - 0,409X, nilai korelasi sebesar $-0,441$ atau memiliki hubungan yang negatif sedang dengan kontribusi pengaruh sebesar 19,8\%, sedangkan sisanya sebesar $81,2 \%$ dipengaruhi faktor lain. Pengujian hipotesis diperoleh nilai $t$ hitung $<\mathrm{t}$ tabel atau $(-1,479<2,262)$. Dengan demikian hipotesis yang diajukan bahwa terdapat berpengaruh signifikan antara Non Performing Loan terhadap Return on Asset ditolak.

\section{IV.KESIMPULAN DAN SARAN}

\section{Kesimpulan}

a. Kondisi variabel Non Performing Loan berdasar pada periode laporan keuangan 11 tahun diperoleh Non Performing Loan rata-rata sebesar 3,31\%.

b. Kondisi variabel Non Performing Loan berdasar pada periode laporan keuangan 11 tahun diperoleh Non Performing Loan rata-rata sebesar 2,68\%.

c. Non Performing Loan tidak berpengaruh signifikan terhadap Return on Asset dengan persamaan regresi $\mathrm{Y}=4,039-0,409 \mathrm{X}$, nilai korelasi sebesar -0,441 atau negatif sedang dan kontribusi pengaruh sebesar $19,8 \%$ sedangkan sisanya sebesar $81,2 \%$ dipengaruhi faktor lain. Uji hipotesis diperoleh nilai t hitung $<\mathrm{t}$ tabel atau $(-1,479<$ 2,262). 


\section{Saran}

a. Pihak manajemen bank agar lebih memperhatikan likuiditas dan menjaga keseimbangan modal perusahaan pada bank dan lebih meningkatkan perolehan capitalnya dalam kegiatannya.

b. Bagi peneliti selanjutnya disarankan untuk melakukan penelitian di luar variabel independen yang digunakan dalam penelitian ini ataupun mengkombinasikan salah satu vaiabel dalam penelitian ini dengan vaiabel lain diluar variabel dalam penelitian ini, agar dapat memperoleh hasil yang lebih bervariatif yang dapat menggambarkan hal-hal apa saja yang dapat berpengaruh terhadap Return on Assets.

\section{DAFTAR PUSTAKA}

Agus Harjito \& Martono, (2010) "Manajemen Keuangan" Yogyakarta: Penerbit Ekonisia.

Agus Sartono. (2010). "Manajemen Keuangan Toeri dan Aplikasi", Edisi keempat, Yogyakarta: Penerbit BPFE.

Algifari. (2015). “Analisis Regresi untuk Bisnis dan Ekonomi”. Yogyakarta: BPFE.

Arikunto, Suharsimi (2014). "Prosedur Penelitian Suatu Pendekatan Praktek". Jakarta: Rineka Cipta.

Bambang Riyanto, (2011). "Dasar-dasar Pembelanjaan Perusahaan". Edisi ke empat, BPFE Yogyakarta.

Fahmi, Irham (2012), "Pengantar Manajemen Keuangan" Cetakan pertama. Bandung: Penerbit Alfabeta.

Imam Ghozali (2017). "Aplikasi Analisis Multivariate Dengan Program SPSS". Edisi Kelima. Semarang: Badan Penerbit Undip.

Istijanto (2014) "Riset Sumber Daya Manusia". Jakarta: PT. Gramedia Pustaka

Jasmani, J. (2018). Pengaruh Kinerja Keuangan Terhadap Harga Saham (Analisis Pada Perusahaan Property dan Real Estate Yang Go Public di Bursa Efek Indonesia. Jurnal Akuntansi Indonesia, 12(2).

Jasmani, J. (2019). The Effect of Liquidity and Working Capital Turnover on Profitability at PT. Sumber Cipta Multiniaga, South Jakarta. PINISI Discretion Review, 3(1), 2938.

Kasmir, (2010). “Pengantar Manajemen Keuangan”, Edisi Pertama, Cetakan kedua, Jakarta: Penerbit Prenada Media.

Kasmir. (2012) “Pengantar Manajemen Keuangan”, Edisi Pertama, Cetakan kedua, Jakarta: Prenada Media.

Kharis, Ismu Fadli (2011). "Studi Mengenai Impulse Buying dalam Penjualan Online". Semarang : Skripsi Universitas Diponegoro

Martono dan Agus Harjito, (2011). "Manajemen Keuangan”, Jakarta: Penerbit Ekonisia.

Munawir (2010), "Analisis Laporan Keuangan”, Edisi Ke Empat, Penerbit Liberty, Yogyakarta.

Santoso, Singgih (2015). "Menguasai Statistik Multivariat". Jakarta: PT Elex Media Komputindo.

Sartono, "Manajemen Keuangan Aplikasi Dan Teori", Edisi Keempat, BPFE, Yogyakarta, 2008.

Sawir, (2003). “Analisis Kinerja Keuangan dan Perencanaan Keuangan Perusahaan”, Cetakan ketiga, Jakarta: Penerbit PT. Gramedia Pustaka Utama.

Sugiyarso, G. dan F. Winarni, "Manajemen Keuangan (Pemahaman Laporan Keuangan, Pengelolaan Aktiva, Kewajiban dan Modal serta Pengukuran

Sugiyono (2017), "Metode Penelitian Administrasi : dilengkapi dengan Metode R \& D". Bandung: Alfabeta. 